\title{
Anaerobic Digestion Process - A Computational Tool to Estimate the Digester Volume and Biogas.
}

Prashant Bhave ( $\nabla$ ppbhave@ci.vjti.ac.in )

Veermata Jijabai Technological Institute https://orcid.org/0000-0003-0407-2354

Pankaj Patil

Veermata Jijabai Technological Institute

\section{Research Article}

Keywords: Anaerobic Digestion, Computational tool, Biochemical Methane Potential (BMP), Estimation, Biogas Production

Posted Date: February 15th, 2022

DOI: https://doi.org/10.21203/rs.3.rs-1265787/v1

License: () (i) This work is licensed under a Creative Commons Attribution 4.0 International License. Read Full License 


\section{Abstract}

The anaerobic digestion process results in the formation of biogas, which serves as a renewable source of energy. Different types of feedstocks produce varying amounts of biogas. Many models have been programmed for the estimation of the volume of biogas produced during anaerobic digestion. This study develops a computational tool for the estimation of the volume of the anaerobic digester and the volume of the biogas produced. The computational tool utilizes three inputs, namely Retention time, daily feed, and type of feedstock, for the estimation. The estimation of biogas of this tool was compared to the model from the design procedures as provided in the literature. An overall gap of 10\% (in the prediction of the biogas production) was shaved off from two of the three reported values of the case studies. The estimation of the volume of the digester (for the same case studies) was observed to be within $\pm 10 \%$ of the reported values. These outputs can be critical for the evaluation of an anaerobic digestion plant as early as in the planning phase.

\section{Statement Of Novelty}

The article describes the development of a computational tool for the estimation of digester volume and biogas produced in an anaerobic digestion process. The computational tool is easy to operate as it receives three basic inputs, namely retention time, daily feed, and type of feedstock. The tool computes eight different types of feedstocks and delivers the output of the estimation. In comparison to a prior model, the tool exhibited an increase in accuracy for estimation of biogas volume, estimated digester volume, and dimensioned the digester for three fixed dome plant designs. The characteristic values of the feedstocks are the crux of the computational tool and are responsible for the accuracy increase.

\section{Introduction}

The anaerobic digestion (AD) process is a process of conversion of complex organic matter (proteins, carbohydrates, lipids, etc.) predominantly into simple end products of methane $\left(\mathrm{CH}_{4}\right)$ and carbon dioxide $\left(\mathrm{CO}_{2}\right)$ [1]. The conversion process is executed by microorganisms (in the absence of oxygen) to produce the end products [2]. The combination of gaseous end products is considered as biogas, which we can harness as a fuel [3]. Thus, the AD process grants the utilization of different types of organic feedstock (TOF) as a renewable source of energy [4]. The ability to employ different TOF is utilized for a dual purpose of reducing waste and generation of energy [5]. The energy generated from various TOF is variable, and Biochemical Methane Potential (BMP) can be used as an indicator. But the BMP value of a particular waste is an experimental estimation of the methane produced in the $A D$ and can be influenced by various factors (physical conditions, chemical conditions, gas measurement systems, etc.) [6]. Hence, we can acquire an approximate estimation of the energy generated from the $A D$ operation. This approximate estimation, with the use of experimentally attained values, can be facilitated by using the said values to develop a mathematical computational tool (CT) [7]. 
Studies have been conducted for the economical assessment of the farm-based AD. The financial feasibility and energy generation through the Combined Heat and Power unit were modeled for maximum profit [8; 9]. The AD calculator was developed for the calculation of daily biogas yield and economical aspects as an improvement to the fixed biogas yield calculators [10]. A software program was modeled which estimated the design and the construction costs of a biogas plant [11].

This study deals with mathematically developing a CT, which estimates the volume of the digester and the volume of the biogas produced due to various TOF. Based on the volume of the digester, the dimensioning of three types of biogas digester designs (BDD) (Fixed Dome Plant Designs - namely Chinese Design, Hemisphere Design, and Deenbandhu Design) have been computed.

\section{Methodology}

The mathematical CT was developed with the help of a Microsoft Excel worksheet. The tool consists of fundamental arithmetic equations, and the solutions of these equations are integrated to forge a chain of equations. Thus, a few selected parameter values are sufficient to generate a required solution as an output. The few selected parameters were retention time (RT, days), Daily Feed (DF, kg/day), and TOF. The input value of RT typically ranges from 10 to 40 days. The DF value is the total amount of feed that would be added to the digester daily. DF was converted from $\mathrm{kg}$ to $\mathrm{Nm}^{3}$ with the help of the typical density of the feedstock. The converted value was retained as Daily Feed Volume (DFV, $\mathrm{Nm}^{3} /$ day). The selection of TOF describes a host of parameters related to a particular feedstock. Each feedstock has a characteristic value of percentage of total solids (TS, \%), percentage of volatile solids to total solids (VS, $\%$ TS), and Biochemical Methane Potential (BMP, $\mathrm{Nm}^{3} / \mathrm{kg} \mathrm{VS}_{\text {added }}$ ).

\subsection{Digester Dimensions}

The input values of parameters, RT and DFV, facilitate the calculation of the volume of the digester (DV, $\left.\mathrm{Nm}^{3}\right)$.

$$
D V=R T * D F V
$$

The DV was considered to be $80 \%$ of the total volume of the digester (TDV). The volume for the gas storage (GSV) was allotted the remaining $20 \%$.

$T D V=D V+G S V$

The TDV calculated from equation (1) was utilized as the volume of the digester in the three BDD as follows:

For Chinese BDD, 
$T D V=\frac{D^{3}}{2.2368}$

Where, $\mathrm{D}$ is the diameter of the digester $(\mathrm{m})$

For Hemisphere BDD,

$$
T D V=\frac{2}{3} \pi\left(\frac{D}{2}\right)^{3}
$$

Where, $D$ is the diameter of the digester $(m)$

For Deenbandhu BDD,

$$
T D V=\frac{2}{3} \pi r^{3}+\frac{1}{6} \pi k\left(3 r^{2}+k^{2}\right)
$$

Where, $r$ is the radius of the digester $(m), k$ is the depth of the curved base $(m)$.

After attaining the fundamental values such as diameter and radius, dimensioning of other dependent values (such as height, dome height, base depth, etc.) was calculated for each digester. The fixed dome BDD was selected to be modeled for their advantages of simple design, absence of moving parts, and long-life span.

\subsection{Methane Production}

Methane production is directly proportional to the VS present in the feedstock. The CT was formulated to calculate the amount of methane produced every day based on the DF. The VS added to the digester was computed based on the TS and the VS of the given feedstock. For calculation of $\mathrm{VS}_{\text {added }}$ in $\mathrm{kg} / \mathrm{day}$, DF was multiplied with the TS and the VS to find its fraction in the DF by the following formula:

$$
V S_{\text {added }}=D F * T S * V S
$$

BMP of feedstock represents the maximum volume of methane produced per $\mathrm{kg}$ of $\mathrm{VS}$ present in the substrate. Hence, the total amount of $\mathrm{VS}_{\text {added }}$ to the digester on daily basis assists in the calculation of the total volume of methane produced daily $\left(V_{M P}\right)$. The $V_{M P}$ is expressed in the units of $\mathrm{Nm}^{3} /$ day.

$$
V_{M P}=B M P * V S_{a d d e d}
$$

The TS, VS, and BMP are the characteristic values that determine the volume of methane produced by a particular feedstock. Table 1 contains these characteristic values for a few TOF obtained from various studies. The values in Table 1 are the mean values of the data gained from the studies and are incorporated in the CT. 
Table 1 The characteristic values of the various TOF used in the CT

\begin{tabular}{|lllll|}
\hline TOF & TS $(\%)$ & VS $(\%$ of TS) & BMP $\left(\mathrm{Nm}^{3} / \mathrm{kg} \mathrm{VS}_{\text {added }}\right)$ & Reference \\
\hline Food Waste & 20.000 & 95.000 & 0.480 & {$[12,13]$} \\
\hline OFMSW & 27.000 & 84.500 & 0.415 & {$[14]$} \\
\hline Dairy Manure & 16.322 & 69.372 & 0.242 & {$[15-18]$} \\
\hline Dairy Slurry & 7.593 & 77.707 & 0.211 & {$[18,19]$} \\
\hline Poultry Manure & 47.598 & 73.004 & 0.258 & {$[15-20]$} \\
\hline Pig Manure & 26.704 & 75.366 & 0.263 & {$[15,18,21,22]$} \\
\hline Maize Silage & 32.094 & 93.706 & 0.417 & {$[18,23-26]$} \\
\hline WWTP ${ }^{b}$ Sludge & 4.482 & 74.274 & 0.323 & {$[18,27-30]$} \\
\hline
\end{tabular}

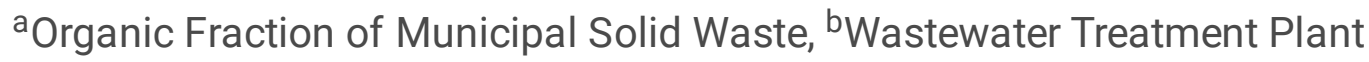

The composition of biogas generally contains $60 \%$ of methane in its total volume [31]. Hence, for computation of volume of biogas produced $\left(\mathrm{V}_{\mathrm{BP}}, \mathrm{Nm}^{3} /\right.$ day), $\mathrm{V}_{\mathrm{MP}}$ was utilized as the following formula:

$$
V_{B P}=\frac{V_{M P}}{0.6}
$$

The $\mathrm{V}_{\mathrm{BP}}$ indicated the estimated volume of biogas produced every day for the given input values.

\subsection{Implementation of Co-digestion in the CT}

Co-digestion is the process of anaerobic digestion of two or more TOF simultaneously. The CT was programmed for co-digestion of two TOF. Two separate DF input options were provided with the ability to select a TOF for each DF input option. The DFV was calculated by the addition of the two DF inputs. The $V_{B P}$ of individual TOF was calculated independently with the help of the characteristic values from Table 1. The summation of individual $V_{B P}$ of the two TOF resulted in the total $V_{B P}$.

\section{Result And Discussion}

The $\mathrm{CT}$ had been programmed to compute the $\mathrm{DV}$ and the $\mathrm{V}_{\mathrm{BP}}$ with the help of three inputs: RT, $\mathrm{DF}$, and TOF. These three inputs could be determined before the construction of the AD plant. The planning stage of the AD plant would be aided with this CT.

\subsection{Estimation of the $V_{B P}$}


Table 2 Comparison of $\mathrm{V}_{\mathrm{BP}}$ estimation by the $\mathrm{CT}$ with a proposed model from the literature [10]

\begin{tabular}{|c|c|c|c|}
\hline Case Study [32] & $\begin{array}{l}\text { Copys Green } \\
\text { Farm }\end{array}$ & Hill Farm & Lodge Farm \\
\hline Feedstock [32] & $\begin{array}{l}\mathrm{DS}^{\mathrm{a}}-6.85 \\
\text { T/day } \\
\mathrm{MS}^{\mathrm{b}}-6.85 \\
\text { T/day }\end{array}$ & $\begin{array}{l}\mathrm{DS}^{\mathrm{a}}-4 \\
\mathrm{~T} / \text { day }\end{array}$ & $\begin{array}{l}\mathrm{DS}^{\mathrm{a}}-30 \mathrm{~T} / \text { day } \\
\mathrm{PM}^{\mathrm{C}}-3 \mathrm{~T} / \text { day }\end{array}$ \\
\hline RT (days) [32] & 45 & 26 & 28 \\
\hline $\mathrm{V}_{\mathrm{BP}}$ Reported ( $\mathrm{Nm}^{3} /$ day) [32] & 1680 & 100 & 1200 \\
\hline $\begin{array}{l}\mathrm{V}_{\mathrm{BP}} \text { estimated by model of } \mathrm{Wu}(2016) \\
\left(\mathrm{Nm}^{3} / \text { day }\right)[10]\end{array}$ & $1360(-19 \%)$ & $100(\sim)$ & $952(-21 \%)$ \\
\hline $\mathrm{V}_{\mathrm{BP}}$ estimated by this study $\left(\mathrm{Nm}^{3} /\right.$ day) & $\begin{array}{l}1573.88 \\
(-6.32 \%)\end{array}$ & $82.99(-17 \%)$ & $\begin{array}{l}1078.48 \\
(-10.13 \%)\end{array}$ \\
\hline
\end{tabular}

${ }^{a}$ Dairy Slurry, ${ }^{b}$ Maize Silage, ${ }^{\text {CPoultry Manure }}$

Table 2 compared the $\mathrm{V}_{\mathrm{BP}}$ estimation of the $\mathrm{CT}$ with a proposed model of Wu (2016) [10]. All the case studies were farm-based $A D$ plants. The $C T$ was able to estimate the $V_{B P}$ more accurately in two of the three case studies. In the first case study and the third case study, the increase in the accuracy of the estimate was observed to be $12.68 \%$ and $10.87 \%$, respectively. In the second case study, $82.99 \mathrm{Nm}^{3} /$ day was estimated for $4 \mathrm{~T} /$ day of feedstock supply. This case study resulted in a decrease in the estimation accuracy by $17 \%$.

\subsection{Estimation of the DV}

Table 3 Comparison of DV estimation by CT with the case studies

\begin{tabular}{|llll|}
\hline Case Study [32] & Copys Green Farm & Hill Farm & Lodge Farm \\
\hline Feedstock [32] & DS -6.85 T/day & DS -4 T/day & DS -30 T/day \\
& MS -6.85 T/day & & PM - 3 T/day \\
\hline RT (days) [32] & 45 & 26 & 28 \\
\hline DV Reported $\left(\mathrm{Nm}^{3}\right)$ [32] & 870 & 105 & 1100 \\
\hline DV estimated by this study $\left(\mathrm{Nm}^{3}\right)$ & $924.75(+6.29 \%)$ & $104(-0.95 \%)$ & $1008(-8.36 \%)$ \\
\hline
\end{tabular}


Table 3 compared the DV of the case studies and the estimation of the CT. The DV is critically dependent on the DF and the RT. The first case study showed a $6.29 \%$ overestimation of the DV. The second and the third case study showed underestimation of the DV by $0.95 \%$ and $8.36 \%$, respectively.

\subsection{Output of Digester Dimension Calculation.}

The dimensions of the cylindrical digester of the Copys Green Farm were reported as $10 \mathrm{~m}$ in diameter and $10 \mathrm{~m}$ in height [32]. The tool estimated the DV of the Copys Green Farm as $924.75 \mathrm{Nm}^{3}$ as reported in Table 3. From Eqn. (2), the TDV of the digester was calculated as $1,155.93 \mathrm{Nm}^{3}$. Fig. 4 displays the output of the tool of digester dimensioning for the various BDD. The reported cylindrical digester was comparable to the Chinese BDD. The similarity was evidenced as the calculated dimensions for Chinese BDD were $13.725 \mathrm{~m}$ in diameter and $9.95 \mathrm{~m}$ in height (summation of $\mathrm{H}, \mathrm{f}_{1}$, and $\mathrm{f}_{2}$ ).

\section{Conclusion}

The CT used three basic inputs (i.e. RT, DF, and TOF) which were utilized for modeling the entire tool. Other key parameters (such as $\mathrm{pH}$, temperature, microorganisms, etc.) were unincorporated [33]. These key parameters are determined during the operation phase of the AD plant and have a dynamic nature (which varies throughout the phases of the AD process if not controlled). The CT attempts to estimate various output values to ease the pre-construction/planning phase. Hence, relatively fixed inputs (which can be determined in the pre-construction phase) were utilized for formulation of the CT. Notwithstanding this handicap, the CT was formulated for the calculation of DV and dimensioning of three different types of BDD. The CT also calculates the $\mathrm{VS}_{\text {added }}$ which facilitated the output of $\mathrm{V}_{\mathrm{BP}}$. The $\mathrm{CT}$ was able to increase the accuracy of the estimation of the $\mathrm{V}_{\mathrm{BP}}$ when compared to a previously well-formulated model. The DV was within the $\pm 10 \%$ range of the reported DV from the case studies. As the future scope of the $C T$, estimation of the energy output of the AD plant can be studied and integrated with this CT. This step will create a complex model for the construction and utilization of the AD technology.

\section{Declarations}

\section{Funding}

No funding was received to assist with the preparation of this manuscript.

\section{Competing Interests}

The authors have no competing interests to declare that are relevant to the content of this article.

\section{Author Contributions}

All authors contributed to the study conception and design. Material preparation, data collection and analysis were performed by Dr. Prashant Bhave and Pankaj Patil. The first draft of the manuscript was 
written by Dr. Prashant Bhave and all authors commented on previous versions of the manuscript. All authors read and approved the final manuscript.

\section{Data Availability}

Data sharing not applicable to this article as no datasets were generated or analysed during the current study.

\section{Acknowledgements}

The authors acknowledge the Royal Agricultural Society of England and the owners of the UK AD plant units for the availability of the data for this research.

\section{References}

1. Zain, M. M., \& Mohamed, A. R. (2018). An overview on conversion technologies to produce value added products from $\mathrm{CH} 4$ and $\mathrm{CO} 2$ as major biogas constituents. Renewable and Sustainable Energy Reviews, 98, 56-63. https://doi.org/10.1016/j.rser.2018.09.003

2. Merlin Christy, P., Gopinath, L., \& Divya, D. (2014). A review on anaerobic decomposition and enhancement of biogas production through enzymes and microorganisms. Renewable and Sustainable Energy Reviews, 34, 167-173. https://doi.org/10.1016/j.rser.2014.03.010

3. Ullah Khan, I., Hafiz Dzarfan Othman, M., Hashim, H., Matsuura, T., Ismail, A., Rezaei-DashtArzhandi, M., \& Wan Azelee, I. (2017). Biogas as a renewable energy fuel - A review of biogas upgrading, utilisation and storage. Energy Conversion and Management, 150, 277-294. https://doi.org/10.1016/j.enconman.2017.08.035

4. Fantozzi, F., \& Buratti, C. (2009). Biogas production from different substrates in an experimental Continuously Stirred Tank Reactor anaerobic digester. Bioresource Technology, 100(23), 5783-5789. https://doi.org/10.1016/j.biortech.2009.06.013

5. Holm-Nielsen, J., Al Seadi, T., \& Oleskowicz-Popiel, P. (2009). The future of anaerobic digestion and biogas utilization. Bioresource Technology, 100(22), 5478-5484. https://doi.org/10.1016/j.biortech.2008.12.046

6. Raposo, F., Borja, R., \& Ibelli-Bianco, C. (2020). Predictive regression models for biochemical methane potential tests of biomass samples: Pitfalls and challenges of laboratory measurements. Renewable and Sustainable Energy Reviews, 127, 109890. https://doi.org/10.1016/j.rser.2020.109890

7. Triolo, J. M., Sommer, S. G., Møller, H. B., Weisbjerg, M. R., \& Jiang, X. Y. (2011). A new algorithm to characterize biodegradability of biomass during anaerobic digestion: Influence of lignin concentration on methane production potential. Bioresource Technology, 102(20), 9395-9402. https://doi.org/10.1016/j.biortech.2011.07.026

8. Jones, P., \& Salter, A. (2013). Modelling the economics of farm-based anaerobic digestion in a UK whole-farm context. Energy Policy, 62, 215-225. https://doi.org/10.1016/j.enpol.2013.06.109 
9. Anderson, R. C., Hilborn, D., \& Weersink, A. (2013). An economic and functional tool for assessing the financial feasibility of farm-based anaerobic digesters. Renewable Energy, 51, 85-92. https://doi.org/10.1016/j.renene.2012.08.081

10. Wu, A., Lovett, D., McEwan, M., Cecelja, F., \& Chen, T. (2016). A spreadsheet calculator for estimating biogas production and economic measures for UK-based farm-fed anaerobic digesters. Bioresource Technology, 220, 479-489. https://doi.org/10.1016/j.biortech.2016.08.103

11. M. Samer. (2010). A Software Program for Planning and Designing Biogas Plants. Transactions of the ASABE, 53(4), 1277-1285. https://doi.org/10.13031/2013.32592

12. Pramanik, S. K., Suja, F. B., Zain, S. M., \& Pramanik, B. K. (2019). The anaerobic digestion process of biogas production from food waste: Prospects and constraints. Bioresource Technology Reports, 8 , 100310. https://doi.org/10.1016/j.biteb.2019.100310

13. Negri, C., Ricci, M., Zilio, M., D’Imporzano, G., Qiao, W., Dong, R., \& Adani, F. (2020). Anaerobic digestion of food waste for bio-energy production in China and Southeast Asia: A review. Renewable and Sustainable Energy Reviews, 133, 110138. https://doi.org/10.1016/j.rser.2020.110138

14. Campuzano, R., \& González-Martínez, S. (2016). Characteristics of the organic fraction of municipal solid waste and methane production: A review. Waste Management, 54, 3-12. https://doi.org/10.1016/j.wasman.2016.05.016

15. Kafle, G. K., \& Chen, L. (2016). Comparison on batch anaerobic digestion of five different livestock manures and prediction of biochemical methane potential (BMP) using different statistical models. Waste Management, 48, 492-502. https://doi.org/10.1016/j.wasman.2015.10.021

16. L. B. Moody, R. T. Burns, G. Bishop, S. T. Sell, \& R. Spajic. (2011). Using Biochemical Methane Potential Assays to Aid in Co-substrate Selection for Co-digestion. Applied Engineering in Agriculture, 27(3), 433-439. https://doi.org/10.13031/2013.37068

17. Angelis-Dimakis, A., Biberacher, M., Dominguez, J., Fiorese, G., Gadocha, S., Gnansounou, E., Guariso, G., Kartalidis, A., Panichelli, L., Pinedo, I., \& Robba, M. (2011). Methods and tools to evaluate the availability of renewable energy sources. Renewable and Sustainable Energy Reviews, 15(2), 11821200. https://doi.org/10.1016/j.rser.2010.09.049

18. Wellinger, A., Murphy, J., \& Baxter, D. (2013). The Biogas Handbook. Woodhead Pub Limited.

19. Allen, E., Wall, D. M., Herrmann, C., \& Murphy, J. D. (2016). A detailed assessment of resource of biomethane from first, second and third generation substrates. Renewable Energy, 87, 656-665. https://doi.org/10.1016/j.renene.2015.10.060

20. Liu, L., Zhang, T., Wan, H., Chen, Y., Wang, X., Yang, G., \& Ren, G. (2015). Anaerobic co-digestion of animal manure and wheat straw for optimized biogas production by the addition of magnetite and zeolite. Energy Conversion and Management, 97, 132-139.

https://doi.org/10.1016/j.enconman.2015.03.049

21. Rodríguez-Abalde, N., Flotats, X., \& Fernández, B. (2017). Optimization of the anaerobic co-digestion of pasteurized slaughterhouse waste, pig slurry and glycerine. Waste Management, 61, 521-528. https://doi.org/10.1016/j.wasman.2016.12.022 
22. Xie, S., Lawlor, P., Frost, J., Hu, Z., \& Zhan, X. (2011). Effect of pig manure to grass silage ratio on methane production in batch anaerobic co-digestion of concentrated pig manure and grass silage. Bioresource Technology, 102(10), 5728-5733. https://doi.org/10.1016/j.biortech.2011.03.009

23. Linke, B., Rodríguez-Abalde, N., Jost, C., \& Krieg, A. (2015). Performance of a novel two-phase continuously fed leach bed reactor for demand-based biogas production from maize silage. Bioresource Technology, 177, 34-40. https://doi.org/10.1016/j.biortech.2014.11.070

24. Mayer, F., Gerin, P. A., Noo, A., Foucart, G., Flammang, J., Lemaigre, S., Sinnaeve, G., Dardenne, P., \& Delfosse, P. (2014). Assessment of factors influencing the biomethane yield of maize silages. Bioresource Technology, 153, 260-268. https://doi.org/10.1016/j.biortech.2013.11.081

25. Mayer, F., Gerin, P. A., Noo, A., Lemaigre, S., Stilmant, D., Schmit, T., Leclech, N., Ruelle, L., Gennen, J., von Francken-Welz, H., Foucart, G., Flammang, J., Weyland, M., \& Delfosse, P. (2014). Assessment of energy crops alternative to maize for biogas production in the Greater Region. Bioresource Technology, 166, 358-367. https://doi.org/10.1016/j.biortech.2014.05.054

26. Moset, V., Al-zohairi, N., \& Møller, H. B. (2015). The impact of inoculum source, inoculum to substrate ratio and sample preservation on methane potential from different substrates. Biomass and Bioenergy, 83, 474-482. https://doi.org/10.1016/j.biombioe.2015.10.018

27. Luostarinen, S., Luste, S., \& Sillanpää, M. (2009). Increased biogas production at wastewater treatment plants through co-digestion of sewage sludge with grease trap sludge from a meat processing plant. Bioresource Technology, 100(1), 79-85.

https://doi.org/10.1016/j.biortech.2008.06.029

28. Jensen, P., Astals, S., Lu, Y., Devadas, M., \& Batstone, D. (2014). Anaerobic codigestion of sewage sludge and glycerol, focusing on process kinetics, microbial dynamics and sludge dewaterability. Water Research, 67, 355-366. https://doi.org/10.1016/j.watres.2014.09.024

29. Girault, R., Bridoux, G., Nauleau, F., Poullain, C., Buffet, J., Peu, P., Sadowski, A., \& Béline, F. (2012). Anaerobic co-digestion of waste activated sludge and greasy sludge from flotation process: Batch versus CSTR experiments to investigate optimal design. Bioresource Technology, 105, 1-8. https://doi.org/10.1016/j.biortech.2011.11.024

30. Pitk, P., Kaparaju, P., Palatsi, J., Affes, R., \& Vilu, R. (2013). Co-digestion of sewage sludge and sterilized solid slaughterhouse waste: Methane production efficiency and process limitations. Bioresource Technology, 134, 227-232. https://doi.org/10.1016/j.biortech.2013.02.029

31. Jeong, C., Kim, T., Lee, K., Song, S., \& Chun, K. M. (2009). Generating efficiency and emissions of a spark-ignition gas engine generator fuelled with biogas-hydrogen blends. International Journal of Hydrogen Energy, 34(23), 9620-9627. https://doi.org/10.1016/j.ijhydene.2009.09.099

32. Bywater, A., Royal Agricultural Society of England, \& Frank Parkinson Agricultural Trust. (2011). A Review of Anaerobic Digestion Plants on UK Farms. https://vm-01-crm02.altido.com/clients/rasec3c5ffc2133a3eed/uploads/documents/website-report/report-document-1.pdf

33. Mao, C., Feng, Y., Wang, X., \& Ren, G. (2015). Review on research achievements of biogas from anaerobic digestion. Renewable and Sustainable Energy Reviews, 45, 540-555. 
Figures

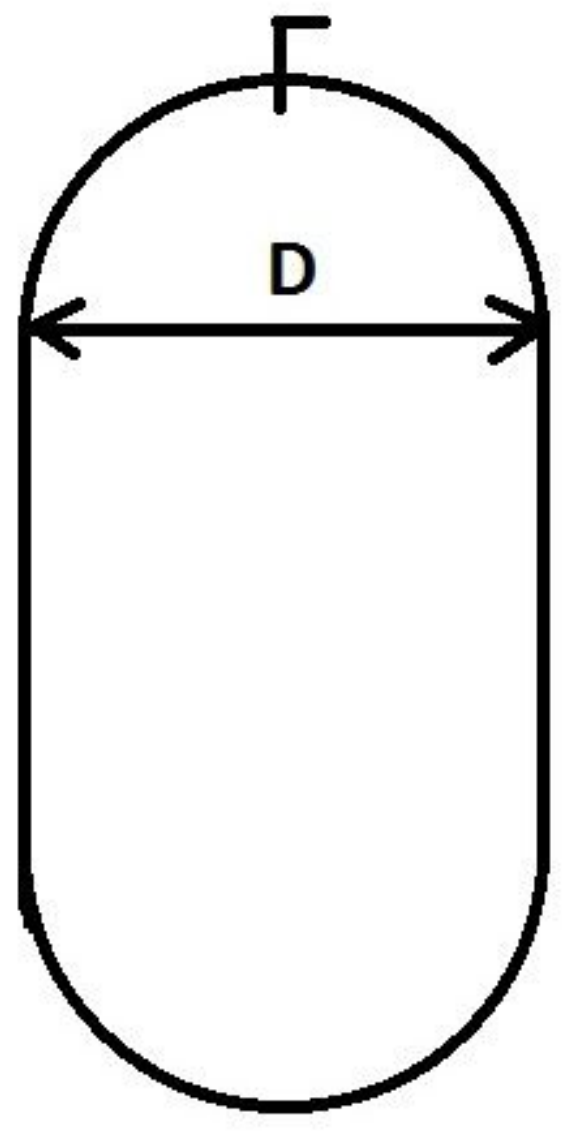

Figure 1

Line Diagram representing the shape and the dimension of the Chinese BDD 


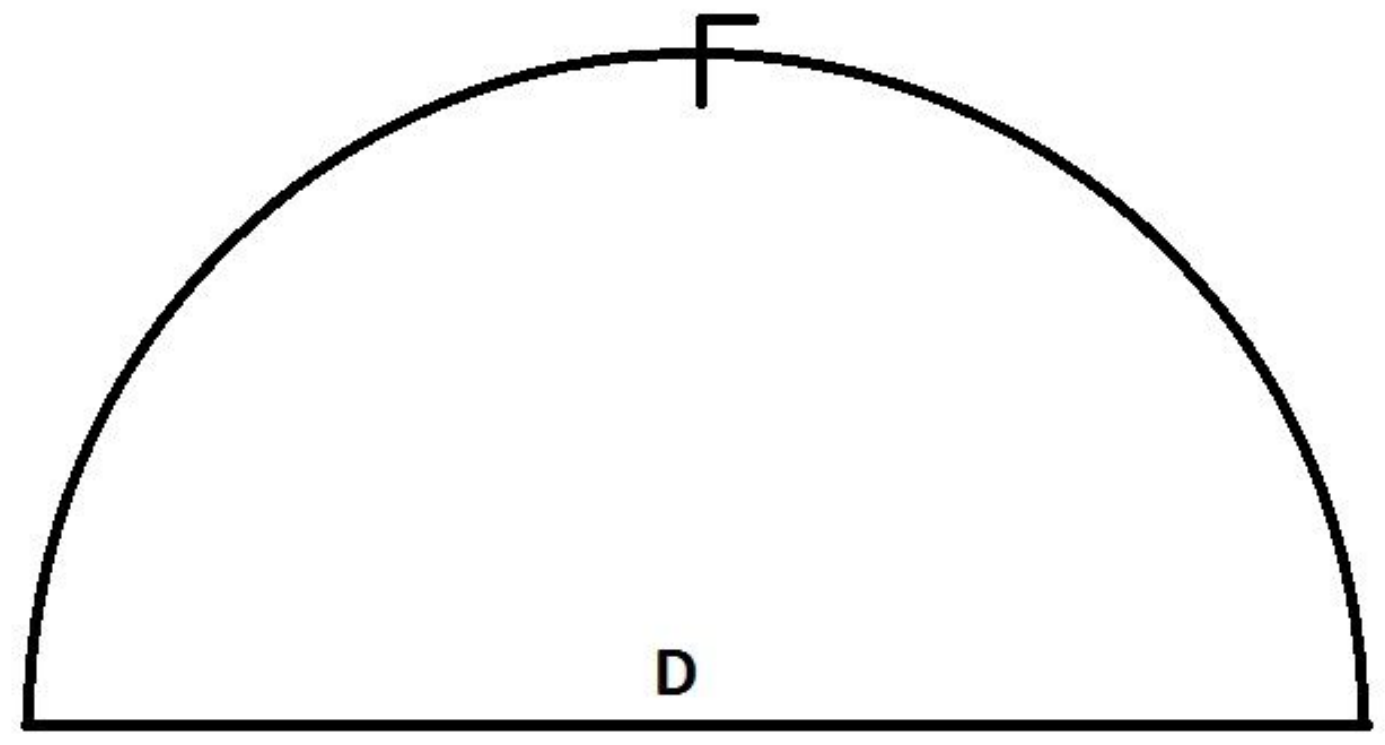

Figure 2

Line Diagram representing the shape and the dimension of the Hemisphere BDD

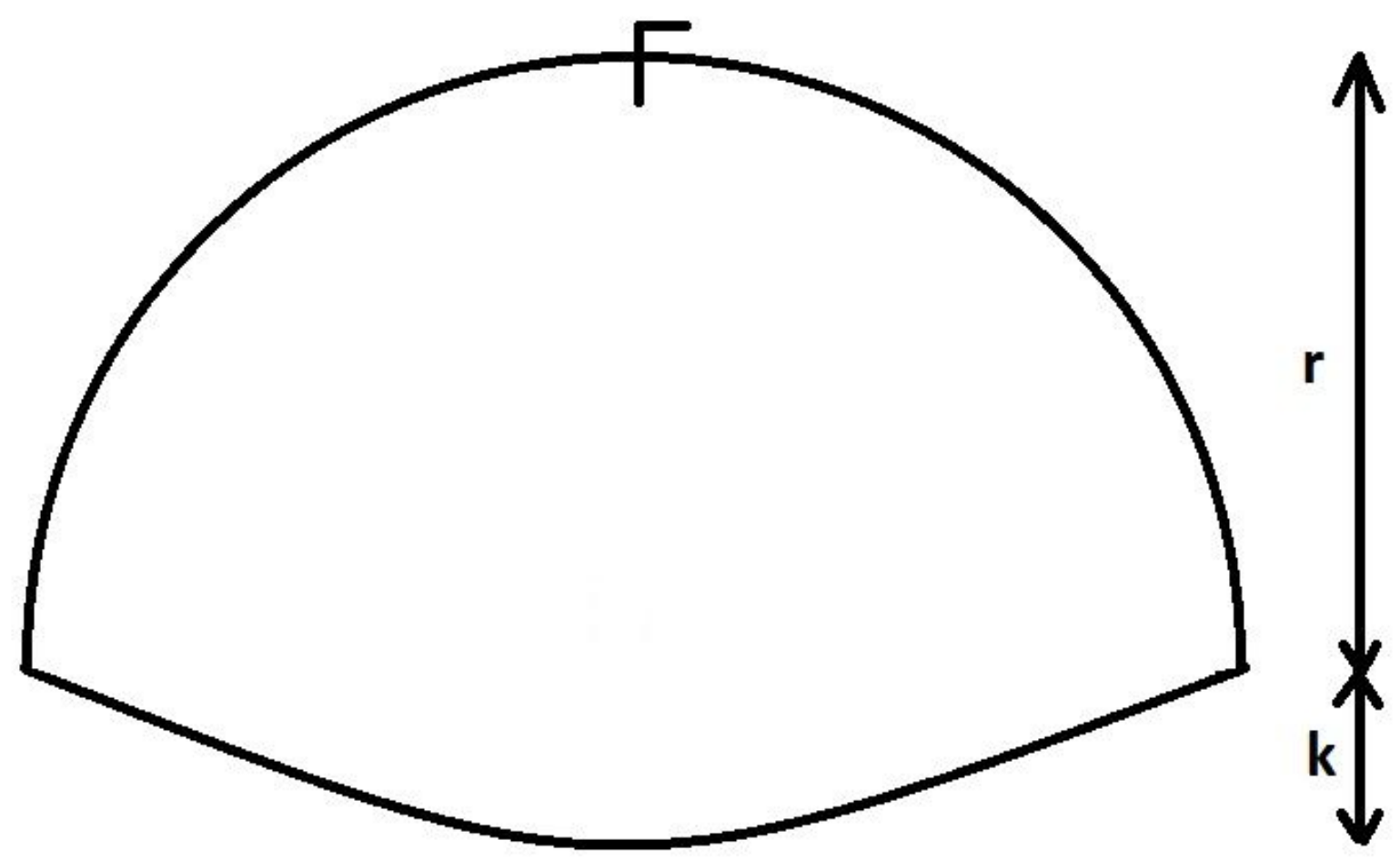

Figure 3 


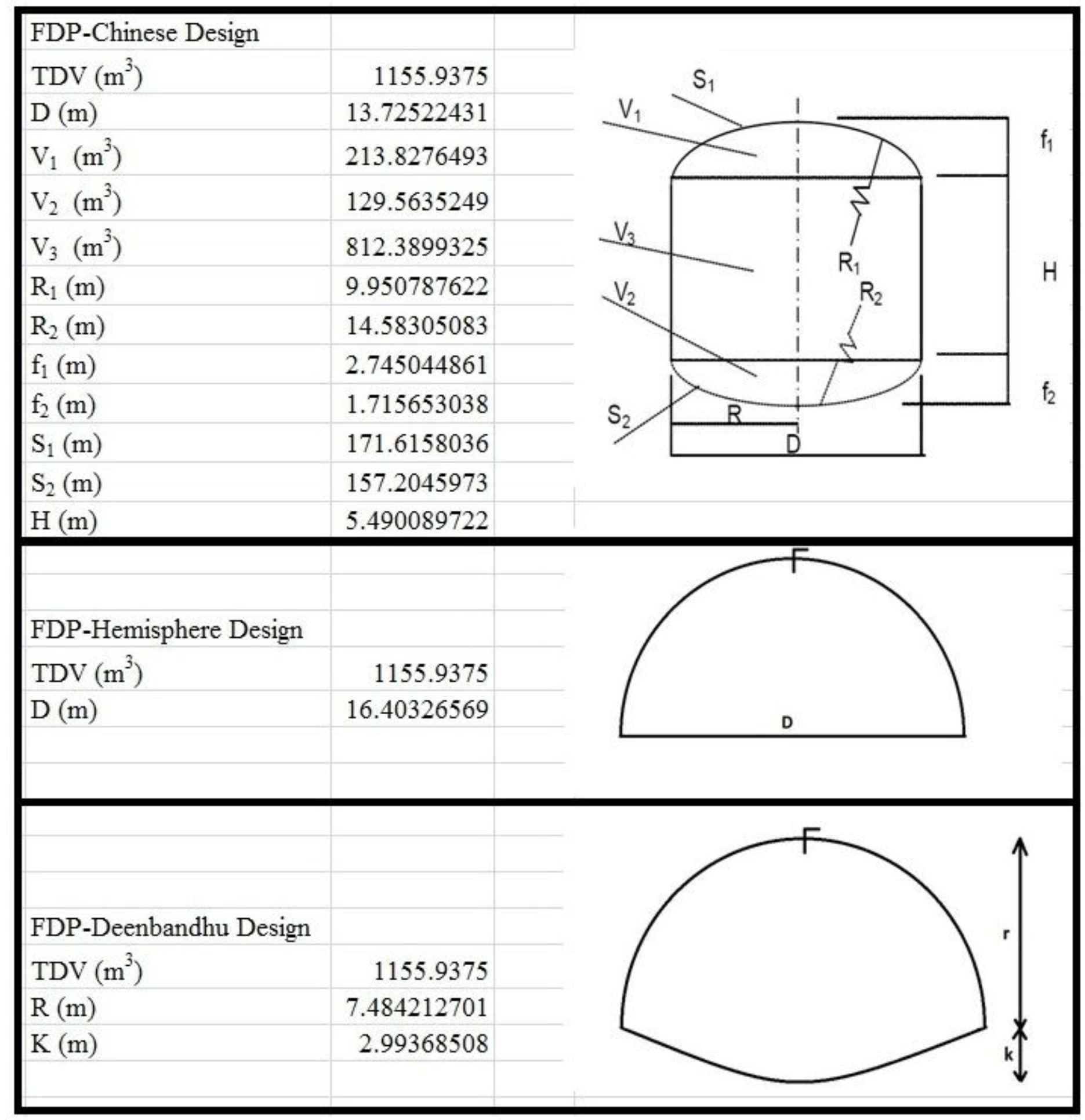

Figure 4

Calculation output of the computational tool for all BDD based on input for the Copys Green Farm

\section{Supplementary Files}


This is a list of supplementary files associated with this preprint. Click to download.

- Graphicalabstract.jpg 